INTERNATIONAL JOURNAL OF MULTIDISCIPLINARY RESEARCH AND ANALYSis

ISSN(print): 2643-9840, ISSN(online): 2643-9875

Volume 05 Issue 02 February 2022

DOI: 10.47191/ijmra/v5-i2-14, Impact Factor: 6.072

Page No. 332-337

\title{
Utilization of The Chronic Disease Management Program (Prolanis) of BPJS Kesehatan in Gowa District-Indonesia
}

\author{
Surahmawati ${ }^{1,}$ Muhammad Rusmin ${ }^{2}$, Nildawati ${ }^{3}$, Syamsul Alam ${ }^{4}$ \\ 1,2,3,4 Public Health Department, Universitas Islam Negeri (UIN) Alauddin Makassar - Indonesia
}

\begin{abstract}
The Chronic Disease Management Program (Prolanis) is an effort of the government and BPJS Kesehatan to carry out health care for BPJS Kesehatan participants who suffer from chronic diseases to achieve optimal quality of life with health care costs effective and efficient. Primary Level Health Facilities (PLHF) such as Puskesmas, Family Doctors, and primary care clinics that have collaborated with BPJS Kesehatan are obliged to implement Prolanis. This study aims to determine the relationship between enabling factors and need factors on the use of Prolanis. This research is a type of analytic survey research with a cross sectional approach which is carried out in several PLHFs, namely; Gentungan Health Center, Manuju Health Center and Tinggi Moncong Health Center. The population in this study were participants in the prolanis activities at the PLHF. The number of samples in this study were 107 people. The results of this study indicate that the factors that influence the use of prolanis in PLHF are; Educational history (0.001), income (0.029), BPJS Kesehatan membership class (0.019), role of health workers (0.001) and timeliness of implementation of prolanis activities (0.048). Factors that do not affect the use of prolanis in PLHF are; Gender (0.369), Age (0.169), Occupation (0.103), Distance from house to PLHF (0.353), Family support (0.413), Knowledge (0.145), Need for prolanis (0.400) and disease control (0.315)
\end{abstract}

KEYWORDS: Chronic Disease, Enabling factors, Need factors, PROLANIS, Utilization of Health care

\section{INTRODUCTION}

Chronic disease is a type of degenerative disease that develops or persists for a very long period of time, which is more than six months. Based on the results of Riskesdas, it was found that there was an increase in the prevalence of non-communicable diseases or chronic diseases. ${ }^{1}$ Riskesdas 2018 when compared to Riskesdas 2013, has increased, including cancer, stroke, chronic kidney disease, diabetes mellitus, and hypertension. Based on examination of blood sugar, the prevalence of diabetes mellitus increased from 6.9 percent to 8.5 percent; and the results of blood pressure measurements, hypertension rose from 25.8 percent to 34.1 percent. ${ }^{1,2}$ Hypertension is still a big challenge in Indonesia because of a condition that is often found in primary health care. This is a health problem with a high prevalence of chronic diseases in Indonesia. In addition, hypertension control is inadequate even though effective drugs are widely available. ${ }^{3}$

Chronic disease is the biggest cause of death with quite a large proportion including very large financing, namely $60 \%$ of the health financing of all people in Indonesia and this chronic disease can be prevented. ${ }^{4.5}$ Therefore, in the treatment of chronic diseases, it is necessary to carry out a health program that is promotive, preventive, curative, and rehabilitative on an ongoing basis. Because if there is no full attention from the start it will have an impact on the high cost of health, so there needs to be a breakthrough program, namely the Prolanis program. ${ }^{5}$

Prolanis is a health service system and a proactive approach implemented in an integrated manner that involves BPJS Participants, Health Facilities and BPJS kesehatan in the framework of health care for BPJS Kesehatan participants who suffer from chronic diseases to achieve optimal quality of life with cost-effective and efficient health services. Prolanis activities encourage participants with chronic diseases to achieve optimal quality of life with an indicator that $75 \%$ of registered participants who visit the First Level PLHF have "good" results on specific examinations for Type 2 DM and Hypertension according to the relevant Clinical Guidelines so as to prevent disease complications. ${ }^{5}$

Primary Level Health Facilities (PLHF) such as Puskesmas, Family Doctors, and primary care clinics that have collaborated with BPJS kesehatan are obliged to implement the Chronic Disease Management Program (Prolanis) initiated by BPJS kesehatan. Based on our observations during the implementation of Prolanis in one of the PLHFs, it was shown that the average involvement 
of BPJS participants who suffered from chronic diseases (hypertension and diabetes) was only $10 \%$, below the target safe zone. This indicates the low utilization of Prolanis services at PLHF BPJS Kesehatan.

Previous research on the use of Prolanis activities shows that there is a significant influence between Prolanis service information ( $p=0.020)$ and schedule / time suitability $(p=0.008)$ on the use of Prolanis in PLK Unair. ${ }^{6}$ While the variables of BPJS class, distance traveled, travel time, availability of transportation, type of transportation, social relations, health workers, health facilities, waiting time and needs do not have a significant effect. ${ }^{6}$ Other studies on factors related to the use of prolanis chronic disease management programs show that there is a significant relationship between knowledge of disease, BPJS kesehatan support and family support with the use of chronic disease management programs. ${ }^{7}$ There is no relationship between age, sex, education, occupation, mileage and travel time to the first level of PPK and peer support with the use of prolanis. ${ }^{7}$ The purpose of this study was to determine the factors associated with the use of the Chronic Disease Management Program (PROLANIS) at the PLHF BPJS Kesehatan in Gowa Regency based on enabling factors and need factors.

\section{SUBJECTS AND METHODS}

This research was conducted in April - May 2020 at PLHFs that have collaborated with BPJS Kesehatan and are temporarily implementing the implementation program for the management of Cornis disease (Prolanis). The selection of research locations was based on the geographical location of the PLHF, which represented lowland areas, namely Gentungan Public Health Center, hilly areas namely Manuju Health Center and upland areas namely Tinggi moncong Health Center.

The sample in this study were KIS / BPJS participants who were registered in the PLHF, registered as prolanis participants and routinely participated in prolanis activities with a total sample of 107 people obtained by total sampling. This type of research is an analytic survey with a cross sectional approach. Primary data were obtained through interviews using a structured questionnaire and secondary data were obtained from health center prolanis managers. Data analysis using the Statistical for Social Science (SPSS) application by presenting sample characteristics, to determine whether there is a relationship between enabling factors and needs factors for prolanis utilization through the Pearson chi square test.

\section{RESULTS}

Based on the results of the research in Table 1, it shows the characteristics of the respondents who took part in prolanis activities, namely that the female gender was the most participant (67.3\%). Age the most is people aged over 59 years (40.2\%). Respondents with the most recent education history were respondents who had completed elementary school (29.9\%). Most of the respondents in the family were members of the family (64.5\%). Most of the respondents' monthly income (60.7\%) is below the provincial minimum wage, that is, with income below Rp. 2,941,270.

Table 1. Distribution of Responden Characteristics

\begin{tabular}{|l|l|l|}
\hline Distribution of Responden Characteristics & $\mathbf{n = 1 0 7}$ & $\mathbf{\%}$ \\
\hline Gender & 35 & \\
Male & 72 & 62.7 \\
Female & & \\
\hline Age & 23 & 21.5 \\
<45 years & 41 & 38.3 \\
45 - 59 years & 43 & 40.2 \\
\hline 59 years & & \\
\hline Education History & 17 & 15.9 \\
Not Schooling Elementary School & 32 & 29.9 \\
Graduated Elementary School & 19 & 17.8 \\
Graduated Junior High School & 19 & 17.8 \\
Graduated Senior High School & 20 & 18.7 \\
Graduated College / Bachelor Degree & & \\
\hline Status in the Family & 38 & 35.5 \\
Head of Household & 69 & 64.5 \\
\hline Household Members & 65 & 60.7 \\
\hline Monthly Income (UMP SULSEL) & 42 & 39.3 \\
\hline <Rp. 2,941,270 & & \\
> Rp. 2.94127 million & & \\
\hline
\end{tabular}


Utilization of The Chronic Disease Management Program (Prolanis) of BPJS Kesehatan in Gowa District-Indonesia

Table 2. Distribution Frequency for Enabling Factors (enabling factor),

Factor Needs and Utilization Prolanis BPJS

\begin{tabular}{|c|c|c|}
\hline Frequency Distribution & $\mathrm{n}=$ & $107 \%$ \\
\hline \multicolumn{3}{|l|}{ Class BPJS Membership } \\
\hline Class I & 38 & 35.5 \\
\hline Classil & 10 & 9.3 \\
\hline Class III & 59 & 55.1 \\
\hline \multicolumn{3}{|l|}{ Distance House To health facilities } \\
\hline$<3 \mathrm{~km}$ & 46 & 43.0 \\
\hline$>3 \mathrm{~km}$ & 61 & 57.0 \\
\hline \multicolumn{3}{|l|}{ Role of health workers } \\
\hline Good & 82 & 76.6 \\
\hline Lack of & 25 & 23.4 \\
\hline \multicolumn{3}{|l|}{ Family support } \\
\hline Good & 84 & 78.5 \\
\hline Lack of & 23 & 21.5 \\
\hline \multicolumn{3}{|l|}{ Knowledge about Prolanis } \\
\hline Good & 59 & 55.1 \\
\hline Lack of & 48 & 44.9 \\
\hline \multicolumn{3}{|l|}{ Punctuality of Prolanis implementation } \\
\hline On time & 79 & 73.8 \\
\hline Not on time & 28 & 26.2 \\
\hline \multicolumn{3}{|l|}{$\begin{array}{l}\text { Variable Needs Factor (Need Based } \\
\text { Factor) }\end{array}$} \\
\hline \multicolumn{3}{|l|}{ Prolanis Service Needs } \\
\hline Requires & 105 & 98.1 \\
\hline Less Need & 2 & 1.9 \\
\hline \multicolumn{3}{|l|}{ Chronic Disease Suffered } \\
\hline Hypertension & 63 & 58.9 \\
\hline Diabetes Mellitus & 20 & 18.7 \\
\hline Hypertension and Diabetes Mellitus & 24 & 22.4 \\
\hline \multicolumn{3}{|l|}{ Utilization of Prolanis Program } \\
\hline Routine & 83 & 77.6 \\
\hline Not Routine & 24 & 22.4 \\
\hline
\end{tabular}

Table 2. Shows the frequency distribution of factors enabling factors, need factors and utilization of the BPJS kesehatan at PLHF. The enabling factorsin this study were based on the membership class of BPJS Kesehatan, most of the respondents were registered as class III participants, namely 55.1\%, the distance from the respondent's house to health facilities, most of which was more than $3 \mathrm{~km}$, namely $57.0 \%$. Most of the health workers were respondents who stated that the role of health workers was good as many as 82 respondents with a percentage of $76.6 \%$, the rest were respondents who stated that the role of health workers was lacking, namely 25 respondents with a percentage of $23.4 \%$. The distribution of respondents based on the most family support was respondents with good family support as many as 84 respondents with a percentage of $78.5 \%$, the rest were respondents with less family support as many as 23 respondents with a percentage of $21.5 \%$. The distribution of respondents based on knowledge about PROLANIS BPJS Kesehatan is mostly respondents with good knowledge about PROLANIS as many as 59 respondents with a 
Utilization of The Chronic Disease Management Program (Prolanis) of BPJS Kesehatan in Gowa District-Indonesia

percentage of $55.1 \%$, the rest are respondents with less knowledge about PROLANIS as many as 23 respondents with a percentage of $44.9 \%$. The most distribution of respondents based on the punctuality of PROLANIS implementation was on time as many as 79 respondents with a percentage of $73.8 \%$, the remaining respondents who stated that the implementation of PROLANIS was not on time were 28 respondents with a percentage of $26.2 \%$.

Table 3. Relationship Factors Enabling / Pusher (Enabling Factor) Utilization against Prolanis BPJS

\begin{tabular}{|c|c|c|c|c|c|}
\hline \multirow[t]{3}{*}{$\begin{array}{l}\text { Factors Enabling / } \\
\text { Pusher (Enabling Factor) }\end{array}$} & \multicolumn{4}{|c|}{$\begin{array}{l}\text { Utilization } \\
\text { Prolanis }\end{array}$} & \multirow[t]{3}{*}{ P-Value } \\
\hline & \multicolumn{2}{|c|}{ Routine } & \multicolumn{2}{|c|}{ Not Routine } & \\
\hline & $\mathbf{n}$ & $\%$ & $\mathbf{n}$ & $\%$ & \\
\hline \multicolumn{6}{|l|}{ BPJS Participation Class } \\
\hline Class I & 35 & 92.1 & 3 & 7.9 & $P=0.019$ \\
\hline Classll & 8 & 80.0 & 2 & 20.0 & \\
\hline Class III & 40 & 67.8 & 19 & 32.2 & \\
\hline \multicolumn{6}{|c|}{$\begin{array}{l}\text { Distance from house to health } \\
\text { facilities }\end{array}$} \\
\hline$<3$ km & 37 & 80.4 & 9 & 19.6 & $P=0.353$ \\
\hline$>3 \mathrm{~km}$ & 46 & 75.4 & 15 & 24.6 & \\
\hline \multicolumn{6}{|l|}{ The Role of Health Officers } \\
\hline Good & 58 & 70.7 & 24 & 29.3 & $P=0.001$ \\
\hline Poor & 25 & 100 & 0 & 0 & \\
\hline \multicolumn{6}{|l|}{ Family Support } \\
\hline Good & 66 & 78.4 & 18 & 21.4 & $P=0.413$ \\
\hline Poor & 17 & 73.9 & 6 & 26.1 & \\
\hline \multicolumn{6}{|l|}{ Knowledge of Prolanis } \\
\hline Good & 43 & 72.9 & 16 & 27.1 & $P=0.145$ \\
\hline Less & 40 & 83.3 & 8 & 16.7 & \\
\hline \multicolumn{6}{|c|}{$\begin{array}{l}\text { Punctuality of Prolanis Implementation } \\
\text { Timely }\end{array}$} \\
\hline \multirow[t]{2}{*}{ Not Timely } & 65 & 82.3 & 14 & 17.7 & $P=0.048$ \\
\hline & 18 & 64.3 & 10 & 35.7 & \\
\hline
\end{tabular}

Table 4. Relationship of Need Based Factors to Utilization of Healthcare BPJS Prolanis

\begin{tabular}{|l|l|l|l|l|l|}
\hline \multirow{2}{*}{$\begin{array}{l}\text { Need Factors } \\
\text { (Need Based Factor) }\end{array}$} & \multicolumn{3}{|l|}{ Utilization of Prolanis } & \multirow{2}{*}{ P-Value } \\
\cline { 2 - 5 } & \multicolumn{2}{|l|}{ Routine } & \multicolumn{2}{l|}{ Not Routine } & \\
\cline { 2 - 6 } & $\mathbf{n}$ & $\%$ & $\mathbf{n}$ & $\%$ & \\
\hline Prolanis Service Need & & & & & \\
Requires & 82 & 78.1 & 23 & 21,9 & \multirow{2}{*}{$\mathrm{P}=0.400$} \\
Less Need & 1 & 50.0 & 1 & 50.0 & \\
\hline Chronic Disease Control After Following & & & & & \\
Prolanis & & & & & \\
Hypertension & 36 & 70.6 & 15 & 29.4 & \\
DM & 1 & 100 & 0 & 0 & $\mathrm{P}=0.315$ \\
Hypertension \&DM & 4 & 100 & 0 & 0 & \\
Normal & 42 & 82.4 & 9 & 17.6 & \\
\hline
\end{tabular}

\section{DISCUSSION}

1. Relationship of enabling factors /Enabling factors for the utilization of the BPJS Kesehatan chronic disease management program (PROLANIS) at the PLHF. 


\section{Utilization of The Chronic Disease Management Program (Prolanis) of BPJS Kesehatan in Gowa District-Indonesia}

Based on the results of the bivariate analysis to determine the relationship between enabling factors and the utilization of BPJS Kesehatan prolanis to produce; $p$-value for participation class is $0.019, p$-value for the distance of the participant's house to PLHF is $0.353, p$-value for the role of health workers, $p$-value for family support is $0.413, p$-value for knowledge is 0.145 and $p$-value for timeliness of implementation is 0.048 .

Enabling factors for participants to take advantage of chronic disease management programs, namely the class of participation, the role of health workers and the timeliness of implementation based on the results of statistical tests resulted in a p-value less than alpha, namely 0.05 , which means that the class of participation, the role of health workers and timeliness of implementation have a relationship to utilization BPJS Health chronic disease management program (Prolanis). This research is in line with research conducted by Viona (2018) which states that the use of prolanis is significantly influenced by the role of health workers. ${ }^{8}$

In a study conducted by Viona (2018) stated that the main reason respondents did not know about the existence of prolanis activities at the puskesmas was because health workers had never provided information about the existence of prolanists. According to research conducted by Abdullah (2017) regarding the factors causing the decrease in the number of visits from chronic disease management program participants at the Minasa Upa Public Health Center in Makassar City, Abdullah argued that the role of health workers has a significant relationship to the number of visits from chronic disease management program participants. The research conducted by Auliya (2018) is in line with this research by stating that the use of prolanics in PLK Unair is influenced by time suitability. ${ }^{8,9,10}$

Enabling factors for the use of prolanis such as the distance from the house to the PLHF, family support and knowledge after the analysis using the chi square test resulted in a $p$ value greater than Alpha, which means that the distance from the house to the PLHF, family support and knowledge are not related to the utilization of BPJS Health prolanis.

This research is not in line with the research conducted by Shella (2019) which states that knowledge, family support, support for health workers and the severity of disease are related to the use of prolanis at public health centers in the city of Semarang. In a study conducted by Shella (2019), it was stated that out of 118 respondents categorized according to the number of visits and participation of respondents in prolanis activities, they were divided into 2 categories, namely, 60 respondents in the low utilization category and 58 respondents in the high utilization category. Based on the results of observations and interviews conducted, Shella (2019) states that there are several possible respondents with the use of prolanis who are still unsure. First, respondents often forget about the implementation date of the prolanis. Second, on the day of the implementation of the prolanis the respondents were in an unhealthy condition. Third, respondents felt that they did not need to participate in pro-planning activities because they felt that their bodies were still healthy. Fourth, if there are other activities or events on the same day as the implementation of the prolanis, the respondents prefer to attend the event. Fifth, there were respondents who physically had difficulty reaching the PLHF to participate in pro-planning activities. Sixth, there is no family accompanying the prolanis activities. The low utilization of prolanis will not only affect the health of the participants but will also affect the payment for the number of capitation received by the puskesmas from BPJS Kesehatan. If the ratio of visiting prolanis participants does not reach the minimum indicator, the number of capitation will decrease. This is able to have an impact on the services that will be provided by the puskesmas to the participants. ${ }^{11}$

2. Relationship of need based factors to the utilization of the BPJS Kesehatan chronic disease management program (PROLANIS) at the PLH.

Based on the results of the bivariate analysis to determine the relationship between need based factors and the utilization of BPJS Health prolanis, the results are; $p$-value of prolanis requirement 0.145 and disease control prolanis participant 0.315 . The need factor in this case is the need for a chronic disease management program and disease control, after an analysis using the chi square test results in a $\mathrm{p}$ value greater than Alpha, so the need for prolanis and disease control is not significantly related to the utilization of the BPJS Kesehatan chronic disease management program. This research is in line with research conducted by Viona (2018) which states that in the work area of the Mandala Public Health Center in 2018, the use of prolanis is not influenced by the need for prolanis services. ${ }^{8}$

Notoatmodjo in Viona (2018) states that the amount of use of health services by a family is a character of the family's disposition, abilities and needs for medical services, so that all these components are considered to have their own role in understanding the differences in the use of health services, while needs are a more important factor. versus predisposing factors and abilities. The greater the perception of the respondent's need for prolanis services, the greater the possibility of increasing the utilization of the BPJS Kesehatan chronic disease management program.

In a study conducted by Vest (2013), it was stated that even if chronic disease sufferers need a chronic disease management program with self-management, with less income and sufficient needs, chronic disease sufferers will experience 
obstacles in carrying out self-management. Similar to this study, out of 107 respondents, only 2 respondents who less need a chronic disease management program, but 23 people who do not routinely follow prolanis. Thus, it can be concluded that the need for a chronic disease management program (prolanis) has no relationship with the use of prolanis. ${ }^{12}$

\section{CONCLUSIONS}

Characteristics of respondents related to the use of chronic disease management programs are the variables of education and income. Characteristics of respondents that were not related to the use of chronic disease management programs were gender, age, and employment status variables. Enabling factors related to the use of chronic disease management programs were the class of participation variables, the role of health workers and the timeliness. Enabling factors that relate to the use of chronic disease management programs are the variable distance from the house to the PLHF, family support and respondent knowledge.

Need based factors, in this case the need for prolanic services and disease control, have no relationship with the use of management programs. chronic disease. However, the results showed that there were positive changes, namely that the respondents did not suffer from Cornis disease based on blood pressure checks and blood glucose levels became normal as much as $47.7 \%$ following prolanis activities regularly.

\section{REFERENCES}

1) Kementerian Kesehatan RI. Laporan Nasional Riskesdas 2018. Lap. Nas. RIskesdas 2018 (2018).

2) Badan Penelitian dan Pengembangan Kesehatan. Riset Kesehatan Dasar (RISKESDAS) 2013. Lap. Nas. 2013 (2013) doi:1 Desember 2013.

3) PERHI. Konsensus Penatalaksanaan Hipertensi 2019. Indonesian Society Hipertensi Indonesia (2019).

4) Setyawan, F. E. B. Sistem Pembiayaan Kesehatan. Magna Medica Berk. Ilm. Kedokt. dan Kesehat. (2018) doi:10.26714/magnamed.2.4.2018.57-70.

5) BPJS. Panduan praktis Prolanis (Program pengelolaan penyakit kronis). BPJS Kesehat. (2014).

6) Arifa, A. F. C. Pengaruh Informasi Pelayanan Prolanis Dan Kesesuaian Waktu Terhadap Pemanfaatan Prolanis Di Pusat Layanan Kesehatan Unair. J. Adm. Kesehat. Indones. (2018) doi:10.20473/jaki.v6i2.2018.95-102.

7) Rahmi, A. N. \& Hidayat, B. Faktor-faktor yang berhubungan dengan pemanfaatan program pengelolaan penyakit kronis di BPJS Kesehatan Kantor Cabang Jakarta Timur Tahun 2015. FKM UI (2015).

8) Yuliaristi, Viona. 2018. Faktor - faktor yang mempengaruhi pemanfaatan prolanis di wilayah kerja puskesmas mandala kecamatan Medan Tembung. Medan. Universitas Sumatera Utara.

9) Abdullah. 2017. Faktor penyebab terjadinya penurunan jumlah kunjungan peserta program pengelolaan penyakit kronis (Prolanis) di puskesmas Minasa Upa Kota Makassar. Jurnal ilmiah kesehatan diagnosis, 11 (4), 383-385, http://ejournal.stikesnh.ac.id/index.php/jikd/article/view/241/129.

10) Auliya, 2018. Pengaruh Informasi Pelayanan Prolanis Dan Kesesuaian Waktu Terhadap Pemanfaatan Prolanis Di Pusat Layanan Kesehatan Unair. Jurnal Administrasi Kesehatan Indonesia Volume 6 No 2. Universitas Airlangga.

11) Mediciani, Shella. 2020. Pemanfaatan Program pengelolaan penyakit kronis di Puskesmas. Higea Journal of Public Health, http://journal.unnes.ac.id/sju/index.php/higea. Universitas Negeri Semarang, Indonesia.

12) Vest et all. Diabetes self-management in a low income population: impacts of social support and relationships with the health care system. Pubmed. 2013;9(2):145-55.

Doi: $10.1177,1742395313475674$.

There is an Open Access article, distributed under the term of the Creative Commons Attribution - Non Commercial 4.0 International (CC BY-NC 4.0)

(https://creativecommons.org/licenses/by-nc/4.0/), which permits remixing, adapting and building upon the work for non-commercial use, provided the original work is properly cited. 